\title{
Geography of Manchuria: Physical and Strategic
}

\section{N. M. Fenneman}

To cite this article: N. M. Fenneman (1905) Geography of Manchuria: Physical and Strategic, Journal of Geography, 4:1, 6-11, DOI: 10.1080/00221340508985563

To link to this article: http://dx.doi.org/10.1080/00221340508985563

曲 Published online: 12 May 2008.

Submit your article to this journal 정

Џ Article views: 3

Q View related articles ๘ 


\title{
GEOGRAPHY OF MANCHURIA
}

\author{
Physical and Strategic. \\ BY N. M. FENNEMAN
}

Professor of Geology, University of Wisconsin, Madison, Wisconsin.

COMPARISON of the campaign now being waged by the Japanese,
with that carried on ten years ago in the war with China, leaves a
very strong impression that the nature and direction of the army movements are being controlled by the surface of the country. The enemy in the former war came from the South; in this war from the North. The former enemy was weak; this one strong. Yet the movements of the opposing armies have been so nearly identical in the two cases that it has well been said that a strategic map of either war would serve to illustrate an account of the other.

Maps. Reliable maps of Manchuria are exceedingly difficult to obtain, if, indeed, they exist at all, outside the circle of the Japanese war department. A search of a number of days for such maps revealed a hopeless confusion and endless contradiction among various authorities. An eminent American strategist has announced his decision to give up as hopeless the location on any map, of places named in the war accounts. This state of affairs gives a pathetic humor to the announcement of the Russian generals after the battle of the Shakhe river, which was to the effect that the battle had been lost for the want of accurate maps which, unfortunately for them, their enemies possessed.

Latitudes and dimensions. Manchuria is a country of large dimensions, nearly 1,000 miles long from the northernmost bend of the Amur river to the Yellow Sea on the South. The average width is nearly 400 miles, giving an area of something less than 400,000 square miles. Accuracy is not possible on account of the contradictory nature of maps with reference to the western boundary. Port Arthur on the Yellow Sea is in the latitude of Washington; Mukden in that of New York; Harbin is as far north as Montreal. This is approximately at the center of the country, so that the northern boundary reaches the latitude of the southern part of Hudson Bay. Vladivostok is in the latitude of Boston, though, to complete the scheme of analogy with American cities, Boston should be some 200 miles farther east.

Climate. These locations at once suggest a large range of climates. In general it may be said that the climate of Manchuria is colder than that which is found in like latitudes in Europe and North America. For the southern part of the area this difference is not great, but in going north the 
departure of the mean annual temperature from the average of this latitude is intensified by the unusual cold of the winters. The climate is markedly of the continental type, and therefore subject to great extremes. With summers slightly warmer than the normal for this latitude, the winters, even at Harbin, are some 36 degrees colder than the normal. This gives to the valley of the Sungari river a winter tenperature similar to that of southern Greenland. The valley of the Amur, as might be expected, is still colder. In New York and adjacent states the difference between January and July average temperatures is for the most part less than 50 degrees. At Mukden the corresponding difference is 70 degrees, and the difference increases northward to go degrees on the Amur river. However, lest it should be supposed that these low winter temperatures indicate a typical Arctic climate, it should be remembered that vegetation depends primarily upon the nature of the growing season and not upon the character of the intervening winters.

The winds of Manchuria, unfortunately, come from the North or Northwest in winter, and from the South or Southeast in summer. In addition to the effect which this has upon extremes of temperature, it exercises a dominant influence upon the distribution of precipitation. The winters are $d r y$; the summer monsoons bring drenching rains. Forty-five days of continuous rain have been known in the valley of the Usuri, an amount sufficient to rot European crops cultivated in European style. It is said, however, that the natives have adapted their agriculture to the peculiar conditions and there is apparently no reason why the broad valleys tributary to the Sungari should not become an agricultural country of great wealth.

Topography. The dominant features of the topography are indicated by the direction of two lofty mountain ranges, the great Kinghan on the northwest, and the Shan-alin or Long White Mountains on the southeast. The latter extends northeast to the Amur and Usuri rivers. At its southwest end, 900 miles away, it dies out in the rugged hills of the Liao-tung peninsula. Probably both of the ranges named are much broader and more complex in their alignment than is indicated upon the very sketchy maps available. On the north side, roughly parallel to the Amur river, but lying south of its broad valley, forming the water-shed between the Amur on the north and the Nonni and Sungari and their tributaries on the south, is a tranverse range with altitudes from 3,000 to 5,000 feet. West of the Liao river is a small range along which the present boundary of southernmost Manchuria is drawn. Between the mountains thus outlined are the broad, comparatively level and seemingly highly fertile valleys of the Nonni in the extreme north, the Sungari and its other tributaries in the center, and the Liao in the south. For long distances within this territory, these valleys lie 
less than 600 feet above sea level. Even the low divide between the Sungari and the Liao is a gently rolling upland of moderate elevation. There is nothing in the nature of the valleys thus outlined to prevent the marching

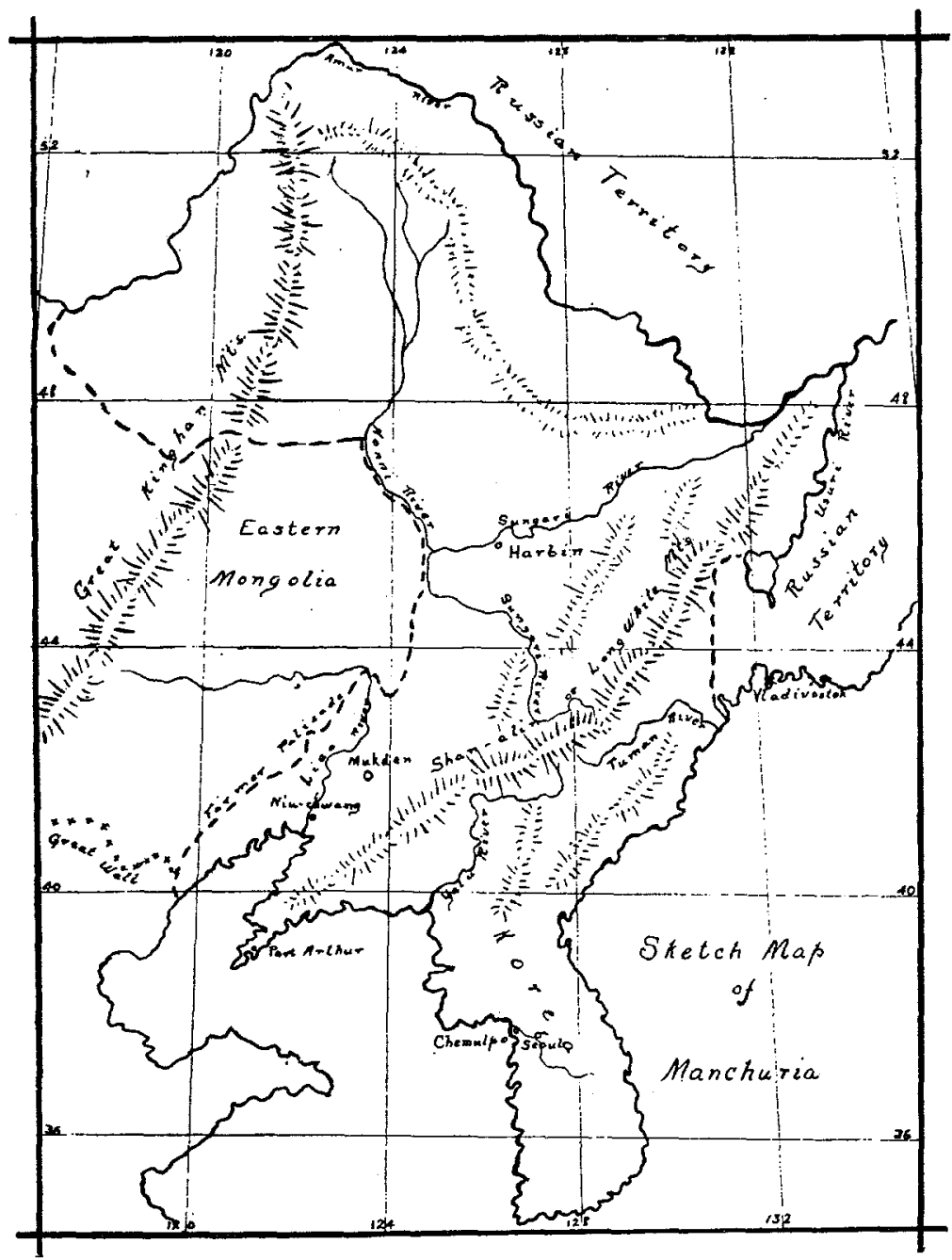

of an army from the shores of the.Yellow Sea to the upper Nonni river, several hundred miles north of Harbin.

Forest and Prairie. The mountains and adjacent hilly country, comprising one-half or probably more than one-half the entire area of the country, are well wooded. The valleys are prairies. It is said, upon the authority 
of Prince Kropotkin, that the prairies of the Amur river are covered in the spring with grass and flowers to a height of four or five feet, and there is apparently equally good authority (Reclus) for the statement that the prairies of the Sungari valley are clothed with grass from eight to ten feet deep, though it is not improbable that this statement applies to the best of the prairies rather than to the average.

Population. This northern area, seemingly so fertile, and so full of promise for the future, is almost uninhabited. The country south of Harbin, and especially the valley of the Liao river, is fairly densely populated, the latter supporting perhaps its full quota of human beings. It is said that the population of southern Manchuria, which extends essentially to the divide between the Liao and the Sungari, is about I2,000,000 people, though statements vary widely. For the remaining four-fifths of the country there seem to be less than $8,000,000$ inhabitants.

Unsatisfactory boundaries. This country of less than 400,000 square miles has 2,500 miles of frontier against Russian territory. The Amur river, running through a broad and fertile lowland, nominally divides that lowland politically into two parts, Russian on the north and Chinese on the south. To those who are familiar with the history of boundary lines, such a division carries the suggestion of extreme weakness. Modern civilization has found out, as some one has said, that rivers are the diameters of communities, and not their circumferences; that trade, and with it all the rest of modern life, gravitates toward the rivers, and there mingles and thereby unifies the life of the country on both sides. Should the country along the Amur become well peopled and civilized, it would seem as impossible to preserve one sovereignty on the north and another on the south as it was to keep the Rhine river German on the one side and French on the other. Or, again, it would seem that the difficulty of maintaining separate sovereignties on the north and south sides of the Amur would be found no smaller than that of erecting separate sovereignties on the north and south sides of the Ohio and Potomac rivers. Rivers may make very good boundary lines between purely administrative divisions, such as counties within a state, or even, in so strong a central government as the United States, between states, where a man may go down to the river bank and cross without any experience to show that a new political division has been entered. But between independent, sovereign and possibly hostile countries, while temporary barriers in times of war, navigable rivers are fatal to continued separation in times of peace.

The boundary between Manchuria and the Russian possessions on the east is fixed at the Usuri river. All the disadvantages which must some day be 
felt in connection with the Amur boundary on the north must here be duplicated. The Usuri valley is already a highway for Russian trade and armies. On the southeast, Korea is separated from Manchuria by the. Tuman river and the Yalu. Transgressions of this boundary afforded the final provocation and immediate occasion for both of Japan's great wars, the one with China, the other with Russia. The causes of these aggressions lay in the natural tendencies of trade. With anything like powerful sovereignties on opposite sides of this boundary line, the $\mathrm{Yalu}$ river would make about as good a frontier for Korea as the Po river would for Italy. The natural frontier of Korea is the Shan-alin mountains, just as the Alps are the natural boundary for Italy. On the west, Manchuria is separated from eastern Mongolia by a purely artificial and invisible line, except at the southernmost end, where the line follows the low ridge mentioned above. The entire boundary of southern Manchuria was for several centuries marked by a wooden palisade, but that has totally disappeared except for occasional widely separated ruins.

Natural boundaries. If a civilization is to grow up in Manchuria with reasonable hopes of stability and peace, it will doubtless be found necessary to rectify these boundary lines in some manner so as to separate adjacent sovereignties along natural lines. It will probably always be found impossible to retain much political or commercial unity between central Manchuria and that part lying -west of the Great Kinghan mountains. It would probably be a gain to the country rather than a loss if it should be relieved of the care of that remote portion of its territory. Similarly on the north, if the Russian is to occupy the northern bank of the Amur river, he might as well occupy the southern side, having his frontiers along the low mountain range which forms the divide between the Amur on the one side and the Nonni and Sungari on the other. This would leave to Russian domination the well unified and naturally delimited valley of the Amur. To Manchuria it would leave the equally well unified basin of the Sungari, and all its tributaries. Should the Russians retain control, as no doubt they will, of the country east of the Usuri river, it might well be found to the advantage of both countries to correct the boundary line by establishing it along the line of the Long White mountains. On the west, it is highly desirable that any sovereign state which may occupy Manchuria should extend its frontiers to the Great Kinghan mountains.

Coast line. The coast of Manchuria is not very different from the coast of Scotland or that of Maine. It is that of a well dissected country of strong relief, partially submerged. The peninsula of Liao-tung, at the end of which Port Arthur stands, is but the low continuation of the Long White mountains. Such a coast is characteristically rich in harbors. The 
Japanese found it easy to effect landings at fifteen or twenty different points in the present war. It is therefore a very easy coast to invade, but for reasons similar to those which have made the good harbors, it is a very difficult coast to subdue or conquer. Port Arthur is a natural basin in a mountainous upland, submerged beneath the waters of the Yellow Sea. The knobs of subdued mountains surround it on its landward side in a way now familiar to all, making a natural fortress of peculiar strength.

Routes of invasion. If the routes followed by the army of invasion be examined, they will be found to have a very close dependence upon the geography here sketched. The initial landing of troops was on the west side of Korea. From this point the comparatively low country was followed to the Yalu river. Considerable resistance was met at this point and a notable battle fought in which it has been said that the Russians occupied the exact heights which were fortified by the Chinese ten years ago, were deceived by the same ruses and went down before the same attacks, coming from the same direction. They then retreated northwestward toward Feng Wang Cheng by the same road followed by the Chinese. At Feng Wang Cheng the road sends out various branches in westerly directions. This place, though a center of travel, was not chosen to be defended, probably because of better opportunities at the passes to the west and northwest. It is here, along the southwestward extension of the Long White mountains leading down to the peninsula of Liao-tung, that a long delay occurred. It was at first reported that the passes of the mountains to the west and northwest were unfortified, and it was supposed that the Japanese were marching without opposition toward Mukden on the north and Hai-tcheng and Niuchwang on the west. Here, however, the natural strategic features of the country came into prominence by a long delay occupied with repeated skirmishes and stubborn fights between comparatively small armies. Despite the earliest reports which gave to the Japanese an unimpeded passage over the low range, it was four long months before the passage was effectually made, and Motien and Daling passes have repeated mention as the scenes of hard fighting until after the battles of Liao Yang and the Shakhe river. This low mountain range safely passed, the complete occupation of the open valley reaching south and north from Mukden was largely a matter of fighting strength, and it would seem to a layman, of geographic rather than strategic interests, that the steady progress of the Japanese northward to Harbin, or of the Russians southward to near Port Arthur, is a matter of hard and skillful fighting rather than of strategic questions based on topography. 